\title{
A EDUCAÇÃO ESCOLAR COMO DIREITO HUMANO DE TRÊS GERAÇÕES: IDENTIDADES E UNIVERSALISMOS
}

\author{
Carlota Boto*
}

\begin{abstract}
RESUMO: Este artigo defende a tese de que o direito à educação se teria desenvolvido em três geraçóes: 1 . $\mathrm{O}$ ensino torna-se paulatinamente direito público quando todos adquirem a possibilidade de acesso à escola pública; 2 . A educação como direito dá um salto quando historicamente passa a contemplar, pouco a pouco, o atendimento a padrôes de exigência voltados para a busca de qualidade no ensino oferecido e para o reconhecimento de ideais democráticos internos à vida escolar; 3. O direito da educação será consagrado quando a escola adquirir padrões curriculares e orientações políticas que assegurem inversão de prioridades, mediante atendimento que contemple - à guisa de justiça distributiva - grupos sociais reconhecidamente com maior dificuldade para participar desse direito subjetivo universal - que é a escola pública, gratuita, obrigatória e laica. Aqui entram as políticas que favorecem, por exemplo, a reserva de vagas por cotas destinadas, nas universidades, a minorias étnicas.
\end{abstract}

Palavras-chave: Escola. Direitos humanos. Democratização do ensino. Educação. Filosofia da educação.

\section{SCHOOL EDUCATION AS THE THREE GENERATION HUMAN RIGHTS: IDENTITIES AND UNIVERSAL TRUTHS}

ABSTRACT: The right to modern education has developed along three generations of levels: 1 . Teaching gradually became a public right, and everyone was allowed in public schools; 2. Education as a right meant a breakthrough when historically, and step by step, it started to meet the standards of demands aimed at providing quality teaching and recognizing the democratic ideas intrinsic to school life; 3. The right to education will become inalienable once schools acquire curricular standards and political guidelines ensuring some

Doutora em história social pela Universidade de São Paulo (FFLCH/USP) e professora de filosofia da educação na Faculdade de Educação da USP. E-mail: reisboto@usp.br

Educ. Soc., Campinas, vol. 26, n. 92, p. 777-798, Especial - Out. 2005 
degree of priority inversion, providing services that, by way of distributive justice, include those social groups that have recognizedly the greatest difficulties to participate in this universal subjective right - the right to attend free and compulsory state schools. And policies reserving quotas of places in universities to ethic minorities, for example, play an essential role to reach that aim.

Key words: School. Human rights. Democratization of teaching. Education. Philosophy of education.

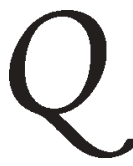

uando são debatidos aspectos concernentes aos direitos humanos que formaram e firmaram a modernidade, habitualmente são consideradas as conquistas históricas de tais direitos, classificando estes por três gerações. Em um primeiro nível, estariam a liberdade e a igualdade civis propugnadas nas primeiras declarações de direitos, junto com a idéia de tolerância religiosa. Esses postulados iniciais ante os direitos dos homens supunham o universalismo da condição do indivíduo humano como agente de direitos. Contudo, derivados das teorias do século XVIII europeu, esses direitos primeiros "são universais em relação ao conteúdo, na medida em que se dirigem a um homem racional fora do espaço e do tempo, mas são extremamente limitados em relação à sua eficácia, na medida em que são (na melhor das hipóteses) propostas de um futuro legislador" (Bobbio, 1992, p. 29).

Posteriormente, desde o reconhecimento público de que tais direitos teriam sido apropriados pelas primeiras declarações que os firmaram - mais particularmente a norte-americana e a francesa -, surge uma segunda etapa no feitio dos direitos públicos; fase esta que confere positividade e torna concreta a legitimação e o reconhecimento dos direitos expressos nas filosofias das Luzes.

Finalmente, a partir da Declaração de 1948 terá início uma terceira fase quando se propugnará a tese de proteção jurídica dos direitos possibilitando a idéia de direito subjetivo, cujo não-cumprimento torna possível ação judicial contra o Estado, garantindo a prerrogativa do direito existente. Desde aquela segunda metade do século XX, ganhariam força as reivindicações específicas por direitos intrínsecos a grupos sociais específicos; que reclamam a identidade na diversidade...

O presente ensaio debruça-se sobre um entrelaçamento de aspectos concernentes ao debate atual a propósito dos direitos humanos e à discussão acerca do temário pedagógico. É freqüente, no discurso da 
educação, oporem-se como antagônicas a idéia da democratização do ensino como extensão de oportunidades de acesso à escolarização e a idéia de uma qualidade de ensino que acompanhe padrões técnico-pedagógicos intrínsecos a uma suposta aplicação de teorias pedagógicas em sala de aula. $\mathrm{O}$ assunto contempla, portanto, a seguinte polêmica: geralmente, quando se irradia a instrução pública - com o fito de progressivamente universalizar seu acesso -, serão incorporadas populações anteriormente excluídas do acesso à escola. Conseqüentemente, há quem denuncie que isso ocasiona um declínio de supostos padróes de qualidade, os quais assegurariam - por definição - alguma excelência do modelo anterior, aquele que contemplava apenas uma parcela diminuta dos que, então, passariam a compor a população escolar. Ao concebermos - como quer Norberto Bobbio - que historicamente os direitos nascem e se desenvolvem, não por nossa disponibilidade pedagógica, mas essencialmente por conjunturas históricas de formações sociais concretamente dadas, poderemos arriscar a tese de que o direito à educação também se teria desenvolvido por patamares postos em três geraçôes:

- o ensino torna-se paulatinamente direito público quando todos adquirem a possibilidade de acesso à escola pública;

- a educação como direito dá um salto quando historicamente passa a contemplar, pouco a pouco, o atendimento a padróes de exigência voltados para a busca de maior qualidade do ensino oferecido e para o reconhecimento de ideais democráticos internos à vida escolar;

- o direito da educação será consagrado quando a escola adquirir padrões curriculares e orientações políticas que assegurem algum patamar de inversão de prioridades, mediante atendimento que contemple - à guisa de justiça distributiva - grupos sociais reconhecidamente com maior dificuldade para participar desse direito subjetivo universal - que é a escola pública, gratuita, obrigatória e laica. Aqui entram as políticas que favorecem, por exemplo, a reserva de vagas por cotas destinadas, nas universidades, a minorias étnicas.

Norberto Bobbio delimita o que apresenta como definição mínima de democracia: "Um conjunto de regras (primárias ou fundamentais) que estabelecem quem está autorizado a tomar as decisões coletivas e com 
quais procedimentos" (Bobbio, 2002b, p. 30). Tal acepção do ideário democrático é bastante adequada se pensarmos historicamente na temática dos direitos humanos e nos procedimentos políticos mediante os quais eles foram postulados e socialmente assumidos como valores coletivos da Humanidade. Bobbio compreende a idéia democrática como progressivo e continuado alargamento do repertório de direitos individuais e coletivos. Tomada dessa forma, democracia é método. Trata-se de um postulado básico de regras e procedimentos de decisóes públicas a serem progressivamente ampliadas para um foro decisório de um maior número de pessoas. Ora, se tomarmos a condição democrática pela efetivação de dispositivos reguladores do jogo social, é necessário acrescer que tais normas deverão ser compartilhadas; e isso, inclusive, em virtude do propósito de os cidadãos (além de deliberarem sobre dinâmicas internas à vida social) deterem consigo o poder de controlar a execução e a própria exeqüibilidade das regras. Diz Bobbio sobre o tema: "A publicidade é por si mesma uma forma de controle, um expediente para distinguir o que é lícito do que não é" (Bobbio, 2002b, p. 42).

A democracia seria, pois, um dado acervo histórico de normas processuais publicamente expostas, cuja lógica é necessariamente dirigida para o contínuo alargamento da tomada coletiva de decisōes. Isso não significa - pondera Bobbio - que não haja a possibilidade institucional da dissensão, do exercício da divergência. Contudo, o modo pelo qual o Ocidente configurou os sentidos da democracia supõe um tácito acordo coletivo sobre as regras norteadoras do jogo político e social. Daí a recorrente dificuldade quando, por exemplo, nos interrogamos sobre as margens incertas entre o tolerável e o intolerável; sobre a fronteira entre o direito da escolha e o dever da obediência ao resultado da mesma escolha etc. No limite, é preciso ser democrata, inclusive, para pensar as confluências e também possíveis assimetrias entre as idéias de particularidade, de pluralismo e de relativismo cultural.

A relação da sociedade diante da categoria operatória dos direitos humanos exige necessariamente que sua própria constituição seja observada mediante o crivo da história; e, no mesmo esquadro, que a reflexão seja pautada pela diretriz de normas coletivas pensadas como universalmente válidas. Isso é artifício, como a própria cultura. Existem leis naturais que possam conferir dignidade à clivagem do direito? Não. Quem "fabrica" a idéia de direito é o homem. Por seu turno, o ser humano é também ele, em alguma medida - sujeito de sua própria construção: da 
natureza, por intermédio da sociedade, o homem se faz cultura. Sob tal consideração, há de se indagar a respeito da existência ou não de fundamentos absolutos legitimadores do direito. Além disso - como sugere Bobbio - caso sejam possíveis, seriam tais fundamentos desejáveis? Existe - pode-se perguntar - uma vocação humana para a liberdade? Seria plausível radicar em algum ponto alguma dimensão de essência, de universalidade da condição humana, no que ela traz de potência ou de especificidade? Como poderíamos qualificar os pilares intrínsecos à acepção de humanidade? Parece-nos haver, de fato, algum impulso naturalmente dado em direção à liberdade. Mas será que é mesmo assim? Parece-nos convidativo o recurso à igualdade como categoria fundadora e irredutível, em última instância, de qualquer projeto humano legítimo. Porém, como conciliar duas distintas exigências - por um lado a liberdade, e por outro a igualdade - se, como sabemos, uma tende a concorrer com a outra? Antes de tudo, é preciso reconhecê-las como manufaturas culturais; ainda que a produção de cultura esteja - ela mesma - alicerçada na própria constituição do ser humano; apresentando-se, por tal razão, como aquilo que nos radica no coração do que ainda nomeamos humanidade. É prudente, portanto, duvidar da "irredutibilidade das crenças últimas" (Bobbio, 1992, p. 22), posto que, no campo dos valores, não há possibilidade de firmar fundamentos razoáveis, se os pensarmos como inamovíveis.

A significação de humanidade, inscrita no coração do debate contemporâneo - a despeito de ser um conceito de matriz universal -, foi construída e firmada pela tradição e pelas trilhas do trajeto civilizatório do Ocidente; embora haja deixado pegadas, rastros e rumos que abarcaram, porventura, povos de matriz não-ocidental. Tratava-se de uma luta, disputada no campo de cenários políticos, envolvendo, entretanto, também uma história das mentalidades - de atmosferas mentais coletivas: um embate que abarcou luta de representações, e cujo desfecho foi favorável ao maior número - pela própria vitória do gênero humano como categoria irredutível de direitos. A idéia de direitos humanos, derivada do conceito histórico de humanidade, contempla uma dimensão de totalidade histórica; sendo, portanto, de cariz mais valoroso, mais democrático, mais generoso, mais amplo e mais fraterno. Sem a significação de humanidade perder-se-iam referências imprescindíveis à própria defesa da condição humana.

Todorov, ao contemplar o tema pela perspectiva antropológica nele inscrita, reconhece que, embora haja a constatação da diversidade huma- 
na como um dado infinito, é possível o reconhecimento coletivo de postulados tidos por universais, para além das fronteiras dos particularismos e das identidades diferenciais. Evidentemente - pondera o autor - a pior forma de discurso universalista é aquela que postula como "naturalmente" universais os valores próprios da sociedade a que pertence o sujeito da enunciação. Para esse viés analítico, do "nosso lado", estaria sempre o "bem"; "o mal" são "os outros" - os que nos causam estranheza e distanciamento. Esse modo de ver o problema é nefasto, posto que, tendo à partida sua própria conclusão, revela absoluta incapacidade para qualquer distanciamento que possibilite a ponderação crítica dos vários aspectos a serem analisados. Todavia, destaca Todorov, essa não é a única possibilidade do ser universalista:

A opção universalista pode se encarnar em diversas figuras. O etnocentrismo merece ser posto à frente, pois é a mais comum dentre elas. Na acepção dada aqui a este termo, consiste em, de maneira indevida, erigir em valores universais os valores próprios à sociedade a que pertenço. $O$ etnocêntrico é, por assim dizer, a caricatura natural do universalista: este, em sua aspiração ao universal, parte de um particular, que se empenha em generalizar; e tal particularidade deve forçosamente lhe ser familiar, quer dizer, na prática, encontrar-se em sua cultura. A única diferença - mas, evidentemente, decisiva - é que o etnocêntrico segue a linha do menor esforço e procede de maneira não-crítica: crê que seus valores são os valores e isso lhe basta; nunca busca verdadeiramente prová-lo. O universalista não-etnocêntrico (pode-se pelo menos tentar imaginar um) buscaria fundar na razão a preferência que sente por certos valores em detrimento de outros; seria particularmente vigilante a respeito daquilo que, embora lhe pareça universal, encontra-se em sua própria tradição; e estaria disposto a abandonar o que lhe é familiar e abraçar uma solução observada num país estrangeiro, ou encontrada por dedução. (Todorov, 1993, p. 21-22)

Abordamos o conceito universal como exigência operatória de nosso próprio processo de raciocínio. E, de qualquer maneira, é preciso transformar o tema em uma questão intelectual a se debater, especialmente quando nós, educadores, lidamos com o cotidiano das situações em que problemas relativos a valores - queiramos ou não - colocam-se no dia-a-dia de nossas salas de aula. Corbett - acerca do tema - é provocador com algum tom de chocante crueza, mas expõe de maneira pertinente o coração da ferida, quando diz: "A ética é um estudo insípido para quem não tenha ainda captado a aparição instantânea do nazista dentro de si” (Corbett apud Archambault, 1979, p. 176). 
Seja como for, trata-se de recorrer à razão e à sensibilidade para fugir de preconceitos, de superstiçōes, de relatos míticos, percepções místicas e, sobretudo, de algum irracionalismo convidativo e - no limite sempre pronto para se fazer de álibi de nossa recusa perante a presença do outro; de nossa desobrigação de convivência com todos os que nos parecem diferentes de nosso padrão identitário... Não será fugindo da clivagem racional que se equacionará o dilema da ética. Antes, pelo contrário, será reivindicando do ato racional o contraponto a possíveis efeitos perversos da mesma racionalidade. Nos termos do que recorda Edgar Morin (1988, p. 85):

O espírito racional era e é universal. A Grécia forjou o discurso racional. A Europa produziu a dialógica, simultaneamente crítica, construtiva e mitológica da razão. Debaixo da palavra "razão" há o melhor e o pior da cultura européia. Foi sob a égide da razão que a dominação desenfreada e o cego desdém das culturas não-européias investiram o mundo. Mas foi o exercício da racionalidade que nos permitiu criticar a razão européia e reconhecer o valor das culturas não-européias. Esta racionalidade nascida na Europa está em vias de universalização. Mas ela é muito frágil. Ela deve ser continuamente protegida, não só dos seus inimigos exteriores, que a impedem de se implantar, mas também do delírio lógico e do demônio mitológico, que a sacode por dentro. É ela que podemos defender, alimentar, fortificar, este fruto derradeiro, o mais precioso, que a Europa no seu declínio pode levar ao universo. É o nosso pássaro de Minerva que se levanta no crepúsculo.

Norberto Bobbio reconhece na democracia a forma de governo que melhor permite aproximar ética e política. Democracia faz-se com a política do reconhecimento de grupos em conflito e do atestado da legitimidade de sua existência. Esse é o primeiro ponto. Além disso, a democracia supõe alguma impessoalidade de regras para arbitrar os jogos de interesses; daí a possibilidade de uma vida comum, hábil para acatar e incorporar as diferenças. Afinal, desde o princípio, a idéia da barbárie tem a ver com a dificuldade de uma população compreender o que diz a outra. Nos termos de Bobbio: "Todo povo tende a considerar a si mesmo como civilizado e rejeita os outros povos como bárbaros. A contraposição entre nós, civilizados, e os outros bárbaros atravessa toda a história do Ocidente. Este juízo, porém, sofre de uma circular reciprocidade: todo povo é bárbaro para o outro" (Bobbio, 2002a, p. 124).

Sucede que, se - para além das identidades - existir o reconhecimento do humano em sua condição de espécie, pode-se dizer que foi o 
trajeto ocidental que, antes, propugnou para todos uma sociedade mais fraterna. Diz Latouche, sobre o tema, que é necessário duvidar de algum modismo do mito identitário; posto que foi uma conquista ocidental a destruição do que ele qualifica por "solipcismo cultural" (Latouche, 1994, p. 129). Mais do que isso, o autor radicaliza quando desnuda possíveis conseqüências da pretensão inscrita em projetos calcados fundamentalmente no reconhecimento de particularidades societárias, mediante irrestrita legitimação de todo e qualquer pluralismo cultural; já que - recorda o autor - "até onde podemos antever o futuro, nunca mais um grupo humano singular poderá se chamar 'os homens', 'os verdadeiros homens" (idem, ibid.).

A acepção primeira de Direitos Humanos remete-nos, de imediato, à tradição ocidental: assim como a idéia de preservação letrada da cultura clássica e o processo de civilização de costumes. Certamente, a tradição escolar que se organiza no Ocidente desde primórdios da Idade Moderna carrega consigo essa herança que, ao mesmo tempo, ajuda a fabricar. Práticas e rituais escolares inventam um modo distinto de ser humano, que, por sua vez, contrapóe-se com frontalidade aos particularismos das camadas populares e, por vezes, até mesmo à língua falada nas comunidades e nas famílias. O latim é introduzido como idioma culto para ser o contraponto autorizado dos linguajares coloquiais. Desde as primeiras escolas religiosas no início do século XVI - pela tradição jesuítica, luterana, calvinista, jansenista etc. -, tratava-se de pôr a público comportamentos prescritos e prevenir condutas proscritas, de modo que, paulatinamente, a escolarização pudesse auxiliar no firmamento da pretendida homogeneidade cultural. Tal intento perpassava o anseio por unidade lingüística.

O Estado - quando se apropria dessa constelação, quando assume para si a tarefa de instrutor das populações e de pedagogo da nação incorpora muitas liturgias construídas e postas em prática pela linguagem da escola moderna (Catroga, 1996). Tratava-se de suplantar e provocar mesmo a erosão dos falares e saberes populares ou comunitários. Era essa a tarefa da nação, firmada pelo Estado.

Viver na sociedade contemporânea - protegido e/ou punido pela mesma legislação; todos iguais - requererá o firmamento de uma igualdade matricial quanto ao acesso às oportunidades de formação. No território pedagógico, a escola é alçada a dispositivo de ruptura com o Antigo Regime - o que a Revolução Francesa fizera no sentido da materialidade 
objetiva deveria se firmar subjetivamente no coração e nas almas de um povo a ser instruído. A escola desenhada pelos revolucionários franceses era tida por universal e única para todos, de maneira que os mais talentosos pudessem "naturalmente" expressar o seu mérito e o seu destaque. Surge como bandeira de luta da escola moderna de Estado o sonho republicano por um sistema de ensino público, gratuito, laico, universal, único e obrigatório. Seria universal por pretender colocar na mesma classe todas as crianças, todos os jovens - meninos e meninas, ricos e pobres, loiros e morenos, católicos, protestantes, judeus ou muçulmanos, habitantes das cidades ou dos campos. Supunha-se único porque o ensino ministrado, no conjunto, deveria ser o mesmo quanto a seus conteúdos e a seus métodos, para todos os estudantes, independentemente de quaisquer identidades e pertenças comunitárias por eles abraçadas.

Não há em nossa contemporaneidade nenhuma carta de direitos e Bobbio sublinha este aspecto - que não identifique o direito à instrução como integrante da construção do próprio estado de direito (Bobbio, 1992, p. 75). Há, nessa medida, um manifesto reconhecimento do valor do esclarecimento e da racionalidade por parte da comunidade internacional, embora protocolos de intençôes nem sempre sejam suficientemente radicados em práticas concretas, especialmente - hoje - nos países situados abaixo da linha do Equador... De todo modo, o apregoado consenso em se propugnar, com firmeza, o direito à educação escolar também se dilui quando se pergunta, àqueles que enunciam seu discurso, sobre aquilo de que se está falando: Quando se advoga o direito à instrução, estaríamos defendendo uma mesma plataforma? (Azanha, 1987) O sentido conferido à idéia de instrução ou de educação escolar é o mesmo? O que dizer sobre a questão dos conteúdos abordados pela escola? O direito à escolarização por tais razões - significa a mesma coisa em todos os lugares em que é hoje declarado?

Parece-nos plausível que aqui nos apropriemos da tese de Norberto Bobbio acerca das três gerações de Direitos Humanos, para o território da educação. Bobbio destaca nitidamente em seus trabalhos que a estruturação dos direitos do homem vieram à tona historicamente por períodos demarcados. Houve uma primeira geração de direitos, que data da plataforma jusnaturalista, desenvolve-se no Iluminismo e tem seu ponto máximo na primeira plataforma dos revolucionários franceses - os direitos políticos: o direito ao voto e à participação na vida civil. Assegurar juridicamente a positividade do direito leva a que - paradoxalmente 
- haja um deslocamento na própria acepção de direitos públicos, considerando-se as primeiras declarações de direito o marco da virada histórica nessa direção.

No transcorrer do XIX, e muito especificamente, nas lutas sociais que se travaram em meados do século e, posteriormente, na Comuna de Paris, a bandeira de luta residirá no que Bobbio qualifica de segunda geração de direitos, os quais - embrionários já na etapa das revoluções burguesas - clamavam pela igualdade. Essa temática conflui para o que hoje qualificamos como direitos sociais: aqueles os quais permitem que - tomando por ênfase a premissa da matricial igualdade humana - os sujeitos possam ter oportunidades equânimes na vida pública, de modo que se reforcem, inclusive, os referidos direitos políticos de primeira geração.

Finalmente, no século XX - com a Declaração dos Direitos Humanos de 1948, com os debates sobre o tema que vêm à tona no final da Segunda Guerra Mundial (em virtude, inclusive, do reconhecimento tácito das atrocidades nela cometidas) e, posteriormente, nos anos que se seguiram aos movimentos jovens da década de 1960 com o irradiar da contracultura - assistiu-se à necessidade de identificar historicamente a exigência de proteção dos direitos assegurados. Percebe-se que:

Quando se trata de enunciá-los, o acordo é obtido com relativa facilidade, independentemente do maior ou menor poder de convicção de seu fundamento absoluto; quando se trata de passar à ação, ainda que o fundamento seja inquestionável, começam as reservas e as oposições. O problema fundamental em relação aos direitos do homem, hoje, não é tanto o de justificálos, mas o de protegê-los. Trata-se de um problema não filosófico, mas político. É inegável que existe uma crise dos fundamentos. Não se trata de encontrar o fundamento absoluto - empreendimento sublime, porém desesperado -, mas de buscar, em cada caso concreto, os vários fundamentos possiveis. (Bobbio, 1992, p. 24)

Além disso, destaca-se - em virtude do impacto do declínio das grandes interpretações de mundo em vigor - a demanda particular por direitos de minorias, consideradas excluídas ou, no mínimo, prejudicadas no tecido social: mulheres, negros, índios, homossexuais, imigrantes, crianças, jovens, idosos, portadores de deficiências... Enfim, do clamor pela igualdade passa-se a fazer notar o vigor das diferenças. A Sociedade Civil passaria, então, a presenciar uma terceira geração de direitos no mundo ocidental: o direito às identidades, à pluralidade cultural e de 
valores, e, mesmo, à defesa de diferenças. Como recorda Bobbio: “(...) os direitos não nascem todos de uma vez. Nascem quando devem ou podem nascer" (idem, ibid., p. 6).

À semelhança das três respectivas etapas de identidade coletiva e especificidade pública dos direitos da Humanidade - anteriormente referidas -, poderíamos, por analogia, enunciar um quadro paralelo para refletir sobre as conquistas e as lutas pela escolarização. Esse quadro procuraremos traçar a seguir:

1. No tocante ao temário educacional, indubitavelmente, os direitos de primeira geração situam-se no postulado de um ensino universal, para todos: o direito de todas as crianças e todos os jovens irem para a mesma escola, até mesmo com o uniforme que disfarça as diferenças. Essa seria, por assim dizer, a primeira exigência quando se pensa a educação como direito público. Seria absolutamente ilegítimo formular o roteiro dos direitos à educação sem considerar democrático tal intento primeiro e primário de expansão das oportunidades escolares. Embora - como assinala Azanha - freqüentemente a extensão da escola seja vista com desconfiada hesitação pelos educadores, especialmente no que diz respeito a um alegado "zelo pedagógico" por um suposto padrão de qualidade que se poderá perder, Azanha recusa qualquer ponderação de ordem técnico-pedagógica para examinar o assunto, qualificando-a como ilegítima. Expandir a escola é imperativo político, sendo, portanto, indeclinável dever do Estado. No que diz respeito à saudosa qualidade do ensino quando a rede de escolas incorpora uma população mais ampla, o erro é óbvio: não se podem aferir padrôes de qualidade sem indagar a quem se atribuem os mesmos padrôes. Diante de uma população que não tem escola, qualquer alargamento da possibilidade de freqüentar a escola é, em si mesmo, um avanço. A qualidade dos poucos que anteriormente tinham acesso privilegiado não possuiria - no parecer de Azanha - qualquer legitimidade para ser invocada. Perante aqueles que, anteriormente, eram dela excluídos, freqüentar a escola é um ganho. Portanto é direito democrático de primeira geração. Direito que, com veemência, Azanha defende - evidenciando a fragilidade dos argumentos contrários a medidas voltadas apenas para incorporar mais crianças à escola... 
O equívoco dessa idéia reside em desconhecer que a extensão de oportunidades é, sobretudo, uma medida política e não uma simples questão técnico-pedagógica. A ampliação de oportunidades decorre de uma intenção política e é nesses termos que deve ser examinada. Aliás, não poderia ser de outra maneira, pois, qualquer que seja o significado que se atribua, atualmente, ao termo "democracia", não se poderia limitar a sua aplicação a uma parcela da sociedade... Não se democratiza o ensino, reservando-o para uns poucos sob pretextos pedagógicos. A democratização da educação é irrealizável intramuros, na cidadela pedagógica; ela é um processo exterior à escola, que toma a educação como uma variável social e não como uma simples variável pedagógica. (Azanha, 1987, p. 41)

2. Consolidado esse primeiro direito político relativo à educação o acesso à escola pública -, será preciso assegurar uma boa qualidade, que possibilite o êxito dos alunos todos no processo de aprendizado. Existe um subterrâneo procedimento excludente interno à escolarização; advindo este de fatores que estão fora da escola: em nome do talento e do dom, é possível desqualificar a criança que se supõe não possuir a mesma capacidade dos outros. A cultura escolar possui, de alguma maneira, um caráter atestador de um dado padrão cultural erudito e letrado, que inclui com facilidade aquelas crianças provenientes de famílias já incluídas no mesmo padrão de letramento erudito. $\mathrm{Na}$ outra margem, são da escola silenciosamente expurgados os jovens que não se identificam com o habitus e com o ethos institucional; jovens que não compartilham - por não terem conhecimento prévio - dos significados culturais inscritos na própria acepção de escola. Para Pierre Bourdieu, a educação escolar exerce sobre as camadas populares níveis sobrepostos de violência simbólica, dado que, além de referendar o capital cultural dos alunos pertencentes às camadas privilegiadas da população, convence aqueles que não são "herdeiros" da mesma cultura erudita de que são eles os responsáveis por seu próprio malogro na escola.

De fato, como toda percepção social, os juízos que os professores fazem a respeito dos alunos, mormente em situação de exame, levam em conta não apenas o saber e o saber-fazer, mas também as nuances imponderáveis das maneiras e do estilo. Trata-se de manifestações ao mesmo tempo imperceptíveis e nunca despercebidas da relação que os indivíduos mantêm com este saber e com este saber-fazer, isto é, expressões semiformuladas, informuladas e 
informuláveis de um sistema de valores que, via de regra, são decifradas em função de um sistema de valores também parcamente formulados e formuláveis. (Bourdieu, 1982, p. 231-232)

A segunda geração de direitos educacionais compreende - à luz desse referido debate crítico - revisar os padrões ideológicos que presidem a orientação de normas de qualidade do ensino público. Para atingir a todos, de maneira mais equânime, seria essencial habilitar a escola e formar professores cônscios das armadilhas que tecem o próprio formato da instituição escolar, para que estes possam fugir das malhas tão perigosas quanto ilusórias do que Maria Helena de Souza Patto (1999) identifica nas teorias que explicitam ora a ideologia do dom e do mérito, ora a tese da carência ou desencontro cultural, ora sistemas protocientíficos de medição de alunos anormais - ou hoje com ditos distúrbios de aprendizagem... Estruturar um razoável padrão de qualidade no ensino que é comum a todos (Beisiegel, 1984) requer revisão dos conteúdos, dos métodos, dos pressupostos e das crenças que norteiam a lógica classificatória excludente da escolarização atual. Há que se rever a carga simbólica expressa pelo conjunto dos saberes formalmente veiculados pela escola. Há que se perscrutar, com perspicácia, possíveis efeitos do currículo oculto que transpõe para a vivência escolar a mesma clivagem de classe que organiza a vida societária em seu conjunto. Os educadores, ao agirem sob a égide dessa consciência, não fariam tudo. Mas - para o âmbito educacional - avançar-se-ia em direção ao que aqui compreendemos ser direito público de segunda geração: todos na escola; em uma escola de boa qualidade - capaz de incorporar crianças de diversas tradiçôes familiares, comunidades e identidades. Pensar nos significados implicados por tal direito de segunda geração constitui, para a pedagogia, traduzir em eficácia concreta o repertório clássico dos saberes escolares nos procedimentos de sua transposição didática, por conteúdos e por métodos de ensino mais ponderados e mais flexíveis, mais críticos e criativos. Permanece, contudo, uma pergunta: Seria isso suficiente?

3. Pode-se, de qualquer modo, intuir a emergência - já bastante evidente, em nossos dias - de uma terceira geração de direitos públicos em educação. $\mathrm{O}$ debate contemporâneo relata a urgência de se revisar a cultura escolar à luz de questóes advindas do debate atinente à diversidade. Os saberes pedagógicos engendrados pela escolarização moderna compõem-se, tal já vi- 
mos, como um vasto relato explicativo; aquilo que alguns certamente chamariam de metanarrativa. Sendo assim, é forçoso reconhecer que os mesmos saberes traduzem uma mundividência de matriz eurocêntrica, masculina, branca, capitalista e ocidental. A cultura da escola contemporânea apresenta a evolução do Ocidente como se de um universal se tratasse. É como se houvesse uma natural linha evolutiva que, progressivamente, aperfeiçoaria os povos "abençoados" pela laicidade do percurso civilizatório de matriz ocidental. Romper algumas amarras simbólicas do conhecimento escolar exigiria um esforço voltado não mais agora para a direção exclusiva da igualdade, ainda que com qualidade, mas, substancialmente, para projetar, acatar e conviver com diferenças: distintas trajetórias, percursos alternativos, diferentes pertenças culturais passam a reivindicar fazer parte do currículo. Um currículo que, aberto quanto aos conteúdos, possa entretecer a diversidade, mobilizando-se pela desconstrução de uma falsa unidade de um saber seqüencial, repartido em disciplinas estanques e hierarquizadas entre si. A terceira geração dos direitos educacionais pauta-se pelo signo da tolerância, mediante a qual o encontro de culturas se faça e se refaça constantemente em uma sempre renovada convivência e partilha entre diferentes nações, diferentes povos, diferentes comunidades, diferentes grupos sociais, diferentes pessoas.

Cabe indagar - para resumir a tese aqui propugnada - se, no trajeto histórico da educação moderna, não teria havido - entre o final do século XVIII (quando o projeto de Estado procura assumir para si a tarefa pedagógica de instituir pela cultura fronteiras simbólicas apropriadas à nação) e o final do século XX (quando a própria idéia de Estado-nação entra em crise) - esse feixe ordenado de três gerações de direitos em educação, especialmente no tocante à imagem de democracia na escola ou de democratização de ensino, tal como ocorreu - talvez mesmo acompanhando - a continuidade de três gerações de direitos públicos, sucessivamente políticos, sociais e identitários/comunitários. Tais direitos só são sucessivos uns aos outros pela clivagem da História.

Em um primeiro momento, teria ocorrido o reconhecimento coletivo dos que aqui são nomeados direitos de primeira geração, embora já houvesse - desde os primórdios da Revolução Francesa - debates concernentes à ação social do Estado perante a idéia de se operacionalizar 
políticas que não eram apenas civis, mas que exigiam investimento público: direitos como os de educação e de saúde, à guisa do que se passaria posteriormente a compreender como igualdade de oportunidades. É fato que também a consideração de identidades diferenciadas se inscrevia na busca de reconhecimento "do outro", o qual, ao lado de sua condição de igual, trazia consigo potenciais e múltiplas particularidades possíveis. Talvez até se possa arriscar dizer que o emblema "liberdade, igualdade e fraternidade" já contivesse - nele inscrita - a equivalência virtual do que compreendemos respectivamente como:

1. direitos civis do indivíduo na sua condição de agente político: a liberdade do voto, mas também a liberdade de opinião - liberdades negativas;

2. a necessidade de ancorar os direitos dessa liberdade primeira em condições de políticas públicas adequadas para o bem-estar da maioria; daí a sugestão de o Estado intervir em setores sociais diretamente - critério imprescindível para materializar nas condições objetivas a igualdade de todos;

3. a percepção de que ser livre e ser igual não elimina o desejo de marcar identidades variadas e distintas especificidades humanas - o que solicita, como contrapartida, a integração da diferença no veio da cultura comum, o reconhecimento do outro pela aceitação, pelo respeito e pela fraterna inclusão.

Historicamente, parece-nos inequívoca a produção de um primeiro consenso que contemplou - não sem ambigüidades - o reconhecimento dos direitos da liberdade humana, no seu sentido negativo. Reconhece-se o homem como sujeito livre e que, portanto, não pode ser privado dessa liberdade matricial. A própria igualdade veio atada, na primeira Declaração de Direitos do Homem e do Cidadão, da França de 1789, à bandeira da igualdade jurídica. Mas a igualdade jurídica trazia consigo a urgência da reivindicação de condiçóes justas de vida comum e compartilhada. Pode-se dizer que, até mesmo para garantir a liberdade da cidadania e da escolha dos representantes por sufrágio popular, havia de se pensar em sentidos outros da igualdade: criava-se o ideário regulador da igualdade das oportunidades sociais como condição e contrapartida da auto-regulação econômica da sociedade liberal. Hoje - já avançando em direção à demarcação do aceite e do respeito a diferenças - percebe-se a preocupação com um leque mais ampliado, que contempla reivindica- 
ções específicas de camadas da sociedade: negros, índios, mulheres, jovens, crianças, idosos, homossexuais, portadores de deficiências - enfim, sujeitos que (sendo iguais) requerem da história do tempo presente a observação e o reconhecimento de suas particularidades.

Embora lidemos, em qualquer dos casos, com conceitos reguladores, categorias operatórias, ou mesmo tipos ideais, no sentido weberiano (Weber, 1979, p. 105), pode-se identificar alguma pertinência no uso de tais categorias para abarcar o que Bobbio compreende ser aquelas referidas geraçōes de direitos, dado que - uma após outra - criam consonâncias, ganham hegemonia e são traduzidas em práticas de políticas públicas. Sendo assim, julgamos não haver mal algum em pensar tais direitos sucessivamente.

Só cem anos depois do tácito reconhecimento do direito ao voto (embora esse voto não fosse ainda universal) é que a intervenção do Estado para assegurar condiçóes materiais de vida às pessoas se tornou efetiva nos países europeus democrático-liberais. Essa segunda geração de direitos exigia investimento público, o que, de algum modo, explicitaria, mais enfaticamente, a distinção entre democratas e liberais. Constituíam-se políticas públicas dirigidas a setores sociais, com o fim de efetivar o direito pleno a se poder ter direitos (Dallari, 1998, p. 69).

Recentemente, o tema da igualdade passou a tomar o contraponto das diferenças - seja pela questão das minorias, seja pela percepção das identidades múltiplas e, mesmo, de particularismos locais constitutivos. Essa terceira geração de direitos traz à tona o debate sobre ações afirmativas, sobre açôes distributivas da ação estatal e sobre a focalização das políticas públicas para o privilégio de setores que historicamente estavam objetivamente excluídos, em maior ou em menor proporção, do usufruto de direitos que, por lei, já seriam seus. Muitas polêmicas da atualidade - a volta das cotas nas universidades, de temas relativos a questôes ecológicas, à bioética, à ação afirmativa, aos direitos das minorias, aos direitos das crianças de não serem maltratadas pela própria família - situam-se, possivelmente, como prognósticos de que nossa contemporaneidade ocidental não concebe, ainda, sem alguma hesitação, a acepção do direito à diferença como contraponto da própria igualdade não cumprida.

De qualquer modo, seja em sentido histórico, seja como exigência lógica, a linguagem requer mobilizar estruturas de pensamento traduzidas por tais julgamentos e expressões - que são invariavelmente tendentes à generalização; e, onde se pretende obter critérios da totalida- 
de, mais haverá dificuldade de correspondência entre jogos de linguagem e sua tradução real. De qualquer forma, não nos poderíamos eximir de expressar a realidade com conceitos. Daí a pertinência da referida construção teórica que distingue, confere clareza a e classifica por geraçōes nossos direitos. Mesmo hoje estamos mais próximos de uns do que de outros; uns mais, outros menos. Tratam-se de opçōes e de valores políticos. Tratam-se de modos distintos de situar a própria acepção de esfera pública. Definindo, com maior precisão, atributos constitutivos de cada geração, teremos maior segurança lógica e confiança reflexiva para mobilizar e operar a grade conceitual que "fala nossos direitos". Nem que seja apenas por tais razōes, vale a pena pensar a história da "democratização do ensino" problematizando, sob enfoque similar, o movimento e as inflexôes postos na mesma expressão. Direitos humanos em educação podem ser concebidos também por geraçōes. Essa é a hipótese aqui desenvolvida.

Talvez haja - como já se procurou anteriormente esboçar - diferentes e sucessivos degraus na edificação dos direitos públicos de educação. Para resumi-los, poder-se-ia dizer que o primeiro deles consistiria, antes de tudo, no reconhecimento da igualdade matricial dos sujeitos perante seu direito de serem todos educados. A seguir, poder-se-ia pensar em critérios norteadores de alguma plataforma no âmbito da qualidade do ensino ministrado, mediante possível flexibilização de conteúdos e de métodos com o fito de obter maior êxito consoante às distintas populações de alunos com que se trabalha. Finalmente, caberia ponderar as necessidades de eqüidade e de justiça para traduzir, no universo da escolarização, algum nível de justiça distributiva, com o propósito de construir o que John Rawls (2001) chamaria de "sociedades razoáveis". Trata-se, nesse caso, de pensar na diversidade, sem abdicar, de maneira alguma, do ainda necessário código de universalidade. Seriam essas o que aqui compreendemos como três geraçóes de direitos educativos.

Quando projetamos a idéia de democracia na escola, a primeira coisa que nos vem à mente é a da democratização do acesso: a oportunidade concreta de todos freqüentarem a mesma escola. Essa era a acepção política - a de primeira geração, que vem à tona nos debates de emancipação do final do século XVIII. Quando, no último quartel do século XIX, o debate pedagógico amplia-se e passa a abarcar questóes relativas a métodos de ensino e à construção progressiva do sítio democrático no interior da unidade escolar e da sala de aula, engendra-se, possivelmente, 
a segunda geração de direitos educativos: a democracia como um conjunto de procedimentos a serem incorporados no âmbito do aprendizado contínuo das regras de um adequado jogo social. Tal orientação, bastante tributária do movimento da Educação Nova, tem sua marca muito acentuada no final do século XIX. Porém, desde meados do século XX, adquire novas colorações, por autores de filiação marxista, com a apropriação feita, pela esquerda, de debate crítico a propósito da organização escolar. Finalmente, pensar na terceira geração da idéia de democracia na escola supõe, certamente, averiguar projetos pedagógicos que estão na base do firmamento de cada cultura educativa em sua especificidade. Desse âmbito - de terceira geração - desdobrar-se-iam reflexões sobre hierarquias, interdições e relações de autoridade externas à sala de aula, mas que dizem respeito ao conjunto da comunidade de cada escola em seus particularismos. Nesse nível, um aspecto que se revela, desde logo, fundamental contempla questões éticas que envolvem a temática da vida escolar pensada sob o signo da democracia. Esse direito, traduzido pela reivindicação do reconhecimento da diversidade, da pluralidade cultural o proclamado direito à diferença -, expressa-se, no mundo contemporâneo, especialmente a partir do último quartel do século XX, quando o debate do pós-modernismo toma conta da reflexão pedagógica, em sua explícita recusa ao que considera ser as modernas e - por suposto - já obsoletas "metanarrativas" de explicação de mundo...

Compreender que há um sentido progressivo na construção daqueles já expressos três degraus de direitos públicos de educação não significa requerer a exclusão de um em nome da primazia de outro. É possível - e em alguma medida desejável - que possamos pensar a contemporaneidade pedagógica à luz da interface entre os três níveis - anteriormente referidos - com que se apresentam as gerações de nossos direitos... Contudo, em um período em que o discurso da autonomia escolar é progressivamente substituído pela defesa do que tem sido qualificado por desterritorialização das políticas educativas, em um tempo no qual as insuficiências da ação nacional reforçam o discurso que fortalece o binômio entre o irredutivelmente local e o irrestritamente global, cabe indagar: enfraquecidas, no limite, as políticas do Estado-nação, quem será alçado como árbitro de conflitos culturais? A Europa unificada ou os Estados Unidos que despovoam povos e devastam territórios, tendo por escudo a alegada defesa do Ocidente? Alain Finkielkraut oportunamente nos recorda de que, quando a idéia de nação nos falta, pode vir a perigosamente 
regressar algum apelo ao recurso da raça, como fronteira de substituição, sendo que, também diz o mesmo autor:

\begin{abstract}
A política em função da nação participava da história humana. A política em função da raça constrói a história da humanidade. A história não é mais o teatro de aventuras múltiplas e entrecruzadas, mas um único processo de fabricação. A ação é pensada como arquitetura: não de trata mais de fazer com, mas de operar, e essa radicalização do poder de fazer implica todo um idealismo da crueldade, todo um puritanismo do mal. (Finkielkraut, 1998 , p. 55)
\end{abstract}

A despeito das encruzilhadas para as quais este diálogo entre educação e direitos humanos nos possa conduzir, cabe recordar que, antes de tudo, uma escola de boa qualidade ainda é, pela lei e pelo direito consuetudinário, dever de Estado e direito subjetivo do cidadão. Que escola é essa? Se possível, a mesma para todos, e - como bem sublinhou Azanha (1987) - isso se deve, antes, a uma inegociável exigência política do que a argumentos provenientes do âmbito pedagógico. Mais do que isso, a escola que projetamos - como algures observou Snyders - será aquela que nos possibilite "desfrutar - em nosso foro íntimo - de tudo o que deveria pertencer à Humanidade inteira”... Tudo o que seja, enfim, mais radicalmente humano porque mais abrangente, mais generoso, mais fraterno; tudo o que incorpore - então - mais gente; tudo o que esclareça melhor pela ação da racionalidade - tudo isso tende, sim, a ser mais universal.

A escola traz, em sua dinâmica interna, a alegria da descoberta de uma cultura outra, que não é mesmo, nem deveria ser, a cultura do dia-adia. O domínio desse repertório clássico supomos ser valoroso para que o estudante decifre melhor enigmas e obstáculos de seu cotidiano. A escola deve ser - ela mesma, por seus ritos, práticas e gestos - esclarecedora, dado que, mesmo que o deseje, não foge da eleição de valores e de postulados de vida. A escola que socializa ensina também. Ensinar o quê? A alegria da descoberta daquilo que, sendo valioso, nem por isso deixa de ser difícil, daquilo que, sendo difícil, convida-nos à alegria cultural do encontro...

Recebido e aprovado em agosto de 2005.

\title{
Referências bibliográficas
}

ALAIN, É.C. Reflexões sobre a educação. São Paulo: Saraiva, 1978.

Educ. Soc., Campinas, vol. 26, n. 92, p. 777-798, Especial - Out. 2005 
ALTHUSSER, L. Ideologia e aparelhos ideológicos do Estado. Lisboa: Presença, 1980.

ARCHAMBAULT, R.D. Educação e análise filosófica. São Paulo: Saraiva, 1979.

ARENDT, H. Entre o passado e o futuro. 2. ed. São Paulo: Perspectiva, 1979.

AZANHA, J.M.P. Experimentação educacional: uma contribuição para sua análise. São Paulo: EDART, 1975.

AZANHA, J.M.P. Educação: alguns escritos. São Paulo: Nacional, 1987.

AZANHA, J.M.P. Uma idéia de pesquisa educacional. São Paulo: EDUSP; FAPESP, 1992.

AZANHA, J.M.P. Educação: temas polêmicos. São Paulo: Martins Fontes, 1995.

BAUDELOT, C.; ESTABLET, R. La escuela capitalista. México, DF: Siglo Veintiuno, 1986.

BEISIEGEL, C.R. Educação e sociedade no Brasil após 1930. In: FausTO, B. (Coord.). História geral da civilização brasileira. (O Brasil republicano; economia e cultura 1930/1964). São Paulo: DIFEL, 1984. v. 4, t. 3, p. 381-416.

BENEVIDES, M.V.M. A cidadania ativa. São Paulo: Ática, 1996.

BOBBIO, N. A era dos direitos. Rio de Janeiro: Campus, 1992.

BOBBIO, N. Elogio da serenidade: e outros escritos morais. São Paulo: UNESP, 2002a.

BOBBIO, N. O futuro da democracia. 8. ed. São Paulo: Paz \& Terra, 2002b. BODEI, R. A filosofia do século XX. Bauru: EDUsC, 2000.

BOURDIEU, P. A economia das trocas simbólicas. 2. ed. São Paulo: Perspectiva, 1982.

CAMBI, F. História da pedagogia. São Paulo: unesp, 1999.

CARDOSO, C.M. Tolerância e seus limites: um olhar latino-americano sobre a diversidade e a desigualdade. São Paulo: UNESP, 2003. 
CATROGA, F. Ritualizações da história. In: Torgat, L.R. et al. História da história em Portugal: séculos XIX-XX. Lisboa: Círculo de Leitores, 1996.

CHANGEAUX, J.-P. (Org.). Uma ética para quantos? Bauru: EDUSC, 1999. CONDORCET. Escritos pedagógicos. Madrid: Talleres Calpe, 1922.

DALLARI, D.A. Direitos humanos e cidadania. São Paulo: Moderna, 1998.

DALLARI, D.; KORCZAK, J. O direito da criança ao respeito. São Paulo: Summus, 1986.

DURKHEIM, E. Sociologia, educação e moral. Porto: Rés, 1984.

ESPINOSA, E.L. (Ed.). Culturas, estados, ciudadanos: una aproximación al multiculturalismo en Europa. Madrid: Alianza, 1995.

FINKIELKRAUT, A. A humanidade perdida: ensaio sobre o século XX. São Paulo: Ática, 1998.

FISCHMANN, R.; BIASOLI-ALVES, Z.M. Crianças e adolescentes: construindo uma cultura da tolerância. São Paulo: EDUSP, 2001.

GIDDENS, A. Modernidade e identidade. Rio de Janeiro: Zahar, 2002.

LASCH, C. Culture of narcissism: American life in an age of diminishing expectations. New York; London: W. W. Norton, 1991.

LATOUCHE, S. A ocidentalização do mundo: ensaio sobre a significação, o alcance e os limites da uniformização planetária. 2. ed. Petrópolis: Vozes, 1994.

MONTERO, P. Diversidade cultura: inclusão, exclusão e sincretismo. In: Dayrell, J. (Org.). Múltiplos olhares sobre educação e cultura. Belo Horizonte: UFMG, 1996. p. 39-61.

MORIN, E. Pensar a Europa. Sintra: Europa-América, 1988.

NAGLE, J. Educação e linguagem: para um estudo do discurso pedagógico. São Paulo: EDART, 1976.

PATTO, M.H.S. A produção do fracasso escolar: histórias de submissão e rebeldia. São Paulo: Casa do Psicólogo, 1999.

PETERS. The concept of education. London: Routledge, 1968. 
POSTMAN, N. O desaparecimento da infância. Rio de Janeiro: Graphia, 1999.

RAWLS, J. O direito dos povos. São Paulo: Martins Fontes, 2001.

SCHEFFLER, I. A linguagem da educação. São Paulo: Saraiva, 1974.

SNYDERS, G. La joie à l'école. Paris: PUF, 1986.

SNYDERS, G. Alunos felizes: reflexão sobre a alegria na escola a partir de textos literários. Rio de Janeiro: Paz \& Terra, 1993.

SNYDERS, G. Feliz na universidade: estudo a partir de algumas biografias. Rio de Janeiro: Paz \& Terra, 1995.

TODOROV, T. Nós e os outros: a reflexão francesa sobre a diversidade humana. Rio de Janeiro: Zahar, 1993. v. 1.

TOURAINE, A. Poderemos viver juntos?: iguais e diferentes. Petrópolis: Vozes, 1998.

WALZER, M. Da tolerância. São Paulo: Martins Fontes, 1999.

WEBER, M. A objetividade do conhecimento nas ciências sociais. In: Cohn, G. (Org.). Weber. São Paulo: Ática, 1979. 